\title{
Characterization of the ToxB Gene from Pyrenophora tritici-repentis
}

\author{
J. Patrick Martinez, ${ }^{1}$ Sean A. Ottum, ${ }^{1}$ Shaukat Ali, ${ }^{2}$ Leonard J. Francl, ${ }^{2}$ and Lynda M. Ciuffetti ${ }^{1}$ \\ ${ }^{1}$ Department of Botany and Plant Pathology, Oregon State University, Corvallis 97331 U.S.A.; ${ }^{2}$ Department \\ of Plant Pathology, North Dakota State University, Fargo 58105 U.S.A. \\ Accepted 26 January 2001.
}

The ToxB gene was cloned and characterized from a race 5 isolate of Pyrenophora tritici-repentis from North Dakota. ToxB contains a 261-bp open reading frame that encodes a 23 amino acid putative signal peptide and a 64 amino acid host-selective toxin, Ptr ToxB. Analysis of Ptr ToxB from heterologous expression in Pichia pastoris confirms that ToxB encodes a host-selective toxin.

Additional keywords: pathogenicity, Ptr chlorosis toxin, tan spot, Triticum aestivum.

Pyrenophora tritici-repentis, the causal agent of tan spot of wheat, is known to produce multiple host-selective toxins (HSTs) (Ciuffetti and Tuori 1999; De Wolf et al. 1998). Isolates can be categorized as one of five races based on the lesion phenotype on four differential wheat lines (Triticum aestivum) (Lamari et al. 1995). Race 1 and 2 isolates produce the proteinaceous HST, Ptr ToxA (Ballance et al. 1989; Tomas et al. 1990; Tuori et al. 1995; Zhang et al. 1997) (syn. Ptr necrosis toxin, Ptr Toxin, and ToxA) (Ciuffetti et al. 1998). Transformation of a nonpathogenic isolate with the gene (ToxA) for Ptr ToxA clearly demonstrated that Ptr ToxA functions as a primary determinant of pathogenicity in the Pyrenophorawheat interaction (Ciuffetti et al. 1997).

Race 5 isolates, first found in Algeria, are characterized by the production of lesions with spreading chlorosis on cultivar Katepwa (Orolaza et al. 1995). Race 5 isolates later were identified in North Dakota (Ali et al. 1999) based on the infection phenotype on four wheat differentials and, specifically, spreading chlorosis on cultivar Katepwa (Fig. 1A). Strelkov et al. (1999) correlated host-specific chlorosis on Katepwa with a 6.61-kDa HST, Ptr ToxB (syn. Ptr chlorosis toxin) and determined by protein sequence analysis 29 of 30 $\mathrm{N}$-terminal amino acids (aa) of the predicted 63 aa protein.

As a strategy to identify other potential HSTs, we are interested in characterizing isolates of $P$. tritici-repentis that lack the ability to produce either Ptr ToxA or Ptr ToxB, yet are pathogenic on specific wheat cultivars. To facilitate this approach, it was necessary to clone and characterize ToxB from a race 5 isolate collected recently in North Dakota (Ali et al. 1999) such that this gene, along with ToxA, could be included in a polymerase chain reaction (PCR)-based

Corresponding author: L. M. Ciuffetti; E-mail: ciuffetl@bcc.orst.edu screen. Cloning ToxB also will facilitate other Ptr ToxBrelated research.

The partial protein sequence of Ptr ToxB (Strelkov et al. 1999) was the basis for the reverse transcriptase (RT)-PCR used to amplify an approximately 300-bp fragment from

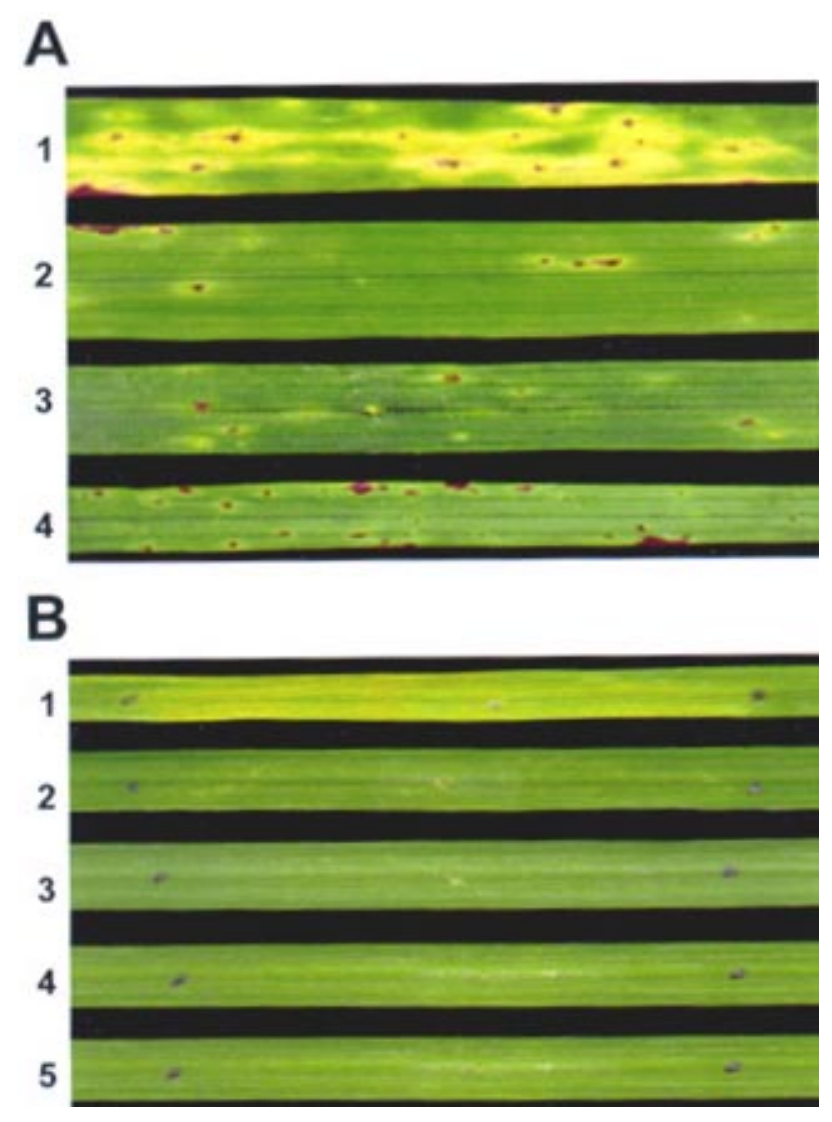

Fig. 1. Pathogenicity and infiltration assays on four wheat genotypes. A, Wheat leaves inoculated with conidia of Pyrenophora tritici-repentis isolate DW7 (race 5) on wheat genotypes Katepwa (1), 6B365 (2), Glenlea (3), and Salamouni (4). Inoculation procedures are described in Faris et al. (1997). B, Leaves infiltrated with $15 \mu 1$ of approximately $20 \mu \mathrm{g}$ of heterologously expressed Ptr ToxB per ml on same wheat genotypes as above (1-4). Katepwa leaf infiltrated with $15 \mu \mathrm{l}$ of culture filtrate $(150 \mu \mathrm{g}$ of total protein per $\mathrm{ml})$ from nontransformed Pichia pastoris (5). Protein concentrations were determined with the $D C$ protein assay (Bio-Rad, Hercules, CA, U.S.A.); lysozyme was used as a standard. Leaves were evaluated for symptoms $72 \mathrm{~h}$ after infiltration. 
cDNA of isolate DW7 with primers TB2 (5'-ATHAAYGARGCNGTIATHGC-3') and CT1 (5'-TTTTGTACAAGCTT ${ }_{30} \mathrm{~V}$ $\mathrm{N}-3^{\prime}$ ). The procedures for cDNA synthesis and RT-PCR were based on methods described by the manufacturer of Superscript II reverse transcriptase (Life Technologies, Bethesda, MD, U.S.A.), except $5 \mu$ of the first-strand reaction were used in a $50-\mu l$ PCR reaction. Sequence analysis confirmed that the approximately 300-bp RT-PCR product encoded part of Ptr ToxB. Thermal asymmetric interlaced (TAIL)-PCR (Liu and Whittier 1995; Liu et al. 1995) was used to gain an additional $5^{\prime}$ and $3^{\prime}$ sequence with genomic DNA and the arbitrary primer TP1 (5'NGTCGASWGANAWGAA-3'). In addition, primers TB3, TB5, and TB6 (Fig. 2) were used for $5^{\prime}$ TAIL-PCR and primers TB7, TB8, and TB9 (Fig. 2) were used for 3' TAIL-PCR. Based on the DNA sequence from the $5^{\prime}$ and $3^{\prime}$ TAIL-PCR products, primers TB10 and TB12 were designed to amplify and sequence a 646-bp fragment from genomic DNA (Fig. 2).

Analysis of the 646-bp fragment revealed a 261-bp open reading frame (ORF) that has no introns and encodes an 87 aa protein with a calculated mass of $8.9 \mathrm{kDa}$. The ORF shows no significant similarity to sequences in the DNA, protein, or protein motif databases. As expected for a secreted protein, however, the first 23 aa fit the criteria for a signal peptide (Martoglio and Dobberstein 1998). The remaining 64 aa appear to encode mature Ptr ToxB (calculated mass of $6.5 \mathrm{kDa}$ ), which is similar in size to the 63 aa predicted by Strelkov et al. (1999). In addition to this slight size discrepancy, there also appears to be differences in amino acid composition. Strelkov et al. sequenced $30 \mathrm{~N}$-terminal aa of Ptr ToxB from Algerian isolate Alg. 3-24. Our DNA sequence data for mature Ptr ToxB from isolate DW7 matches 28 of 30 aa, as reported by Strelkov et al. (1999). The DNA sequence from DW7 encodes a cysteine at aa 2 and 18, reported as an unknown amino acid and a serine, respectively, by Strelkov et al. (1999). Our DNA data was verified by sequence analysis of $19 \mathrm{~N}$-terminal amino acids of Ptr ToxB from isolate DW7. Protein for sequence analysis was first obtained by partially purifying culture filtrate with carboxymethyl-Sephadex chromatography, as described by Strelkov et al. (1999). Ptr ToxB preparations were resolved on a denaturing, $10 \%$ tricine polyacrylamide gel, electroblotted onto polyvinylidene difluoride membrane, and stained with Brilliant Blue-G colloidal (Sigma, St. Louis, MO, U.S.A.). An approximately $6.6-\mathrm{kDa}$ protein band was excised from the membrane and submitted for sequence analysis (Biotechnology Laboratory, University of Oregon).

Southern analysis suggested that more than one copy of To $x B$ or To $x B$-like sequences are present in isolate DW7 (data not shown). Therefore, to confirm that the cloned gene encoded Ptr ToxB, this gene was expressed heterologously in Pichia pastoris in buffered minimal methanol media, in accordance with instructions for the EasySelect Pichia expression kit (Invitrogen, Carlsbad, CA, U.S.A.). P. pastoris was transformed with vector pCM1 by electroporation. To construct pCM1, primers TB15 (5'-TAGCTCGAGAAAAGAAACTGCGTCGCCAATATC-3') and TB16 (5'-ATAGTTATGCGGCCGCTATACCTAATGTAGG-3') were used to amplify the sequence encoding the mature 64 aa Ptr ToxB protein. The purified PCR product was digested with XhoI and NotI and cloned flush with the Kex2 cleavage site of the P. pastoris expression vector $\mathrm{pPICZ} \alpha \mathrm{B}$. Culture filtrate from $P$. pastoris transformed with pCM1 was lyophilized, resuspended in water at approximately $1 / 10$ the original volume, and dialyzed overnight at $4^{\circ} \mathrm{C}$. Culture filtrate from nontransformed P. pastoris for use as a control was processed as described above. Ptr ToxB was purified further from $P$. pastoris culture filtrate by cation exchange chromatography with a MonoS HR 5/5 column (Pharmacia, Piscataway, NJ, U.S.A), as described by Strelkov et al. (1999). Katepwa leaves (susceptible to race 5) became chlorotic when infiltrated with heterologously expressed Ptr ToxB, whereas leaves of the three resistant cultivars, Glenlea, 6B365, and Salamouni, were asymptomatic (Fig. 1B). These results are consistent with infiltrations of Ptr ToxB purified from Algerian isolates (Strelkov et al. 1999). Unfortunately, we were unable to obtain any of the race 5 Algerian isolates (Orolaza et al. 1995; Strelkov et al. 1999) to compare with our North American race 5 isolate.

Screening large numbers of tan spot isolates for the ability to produce Ptr ToxA or Ptr ToxB (or lack there of) can be te-

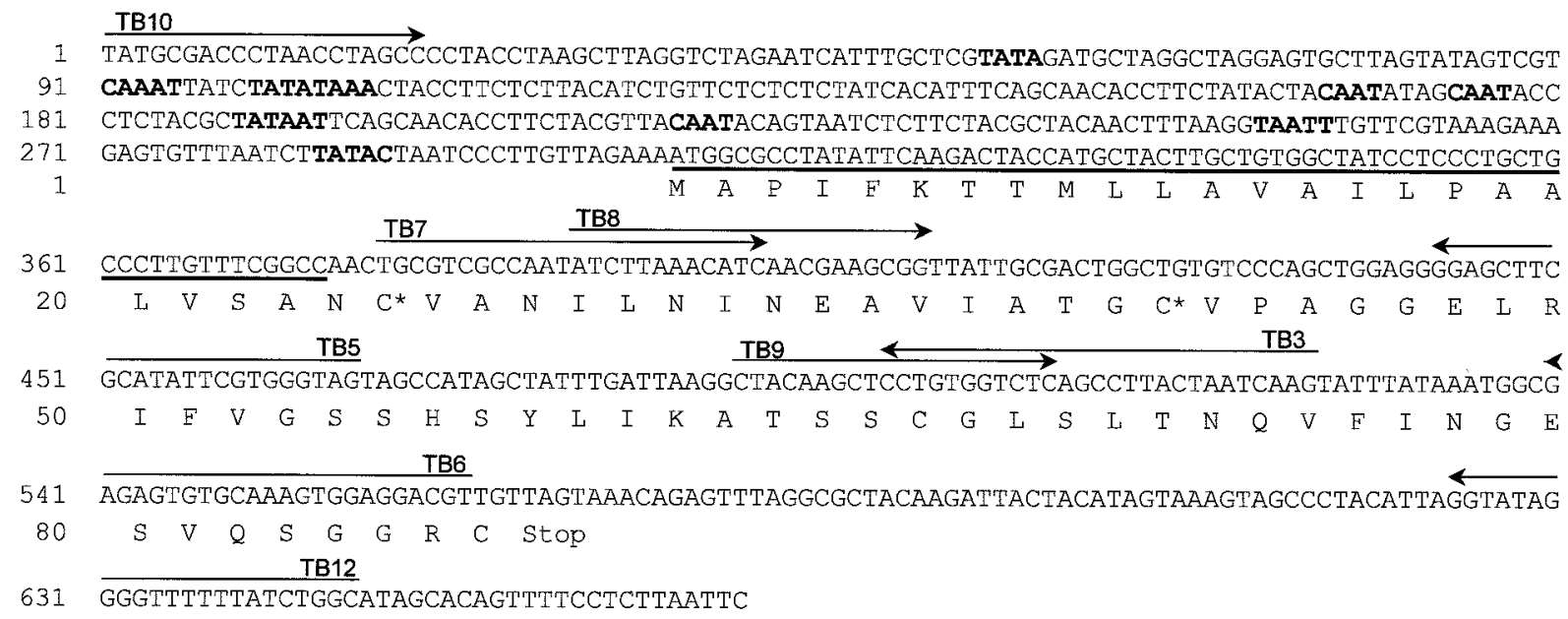

Fig. 2. Sequence analysis of the ToxB gene from Pyrenophora tritici-repentis. Potential CAAT motifs and TATA boxes are in bold (Gurr et al. 1987). Arrows indicate the location and sequence of polymerase chain reaction primers. The DNA sequence for a putative signal peptide is underlined (amino acids 1-23). Amino acids 24-87 represent mature Ptr ToxB. Asterisks indicate differences in amino acids between our data and the data presented by Strelkov et al. (1999). Nucleotide and amino acid data for ToxB have been submitted to GenBank, accession no. AY007692. 
dious, and conidial inoculation onto wheat differentials and the isolation of toxins from culture filtrates can be time consuming and laborious. The cloning of ToxB will enable us to develop a multiplex-PCR screening approach that may serve as a quick primary screen for ToxA and ToxB in $P$. triticirepentis. Unlike the single-copy HST gene ToxA (Ballance et al. 1996; Ciuffetti et al. 1997), ToxB appears to be present in multiple copies (data not shown). Further investigation of additional ToxB loci may provide information about different forms of Ptr ToxB or the evolution of ToxB. Heterologous expression of ToxB in $P$. pastoris enabled us to demonstrate that the cloned ToxB locus encodes a HST. Only Katepwa leaves exhibited typical toxin-induced chlorosis when infiltrated with heterologously expressed Ptr ToxB. Heterologous expression of Ptr ToxB will facilitate additional studies requiring significant quantities of protein such as antibody production, host receptor studies, and crystallography. Given the results presented here and from past studies (Orolaza et al. 1995; Strelkov et al. 1999), it is likely that Ptr ToxB is a primary pathogenicity determinant. This can now be verified by transformation of a $T o x B^{-}$isolate with the ToxB gene.

\section{ACKNOWLEDGMENTS}

This research was supported in part by the U.S. Department of Agriculture Cooperative State Research Service (grant 97353034563). We thank B. Baker (Oregon State University) for assistance with figures, V. Manning (Oregon State University) with heterologous expression of Ptr ToxB, and D. A. McMillen (University of Oregon) for assistance with protein sequence analysis.

\section{LITERATURE CITED}

Ali, S., Francl, L. J., and De Wolf, E. D. 1999. First report of Pyrenophora tritici-repentis race 5 from North America. Plant Dis. 83:591.

Ballance, G. M., Lamari, L., and Bernier, C. C. 1989. Purification and characterization of a host-selective necrosis toxin from Pyrenophora tritici-repentis. Physiol. Mol. Plant Pathol. 35:203-213.

Ballance, G. M., Lamari, L., Kowatsch, R., and Bernier, C. C. 1996. Cloning, expression and occurrence of the gene encoding the Ptr necrosis toxin from Pyrenophora tritici-repentis. Mol. Plant Pathol. Online only: http://www.bspp.org.uk/mppol/1996/1209ballance.
Ciuffetti, L. M., and Tuori, R. P. 1999. Advances in the characterization of the Pyrenophora tritici-repentis-wheat interaction. Phytopathology 89:444-449.

Ciuffetti, L. M., Tuori, R. P., and Gaventa, J. M. 1997. A single gene encodes a selective toxin causal to the development of tan spot of wheat. Plant Cell 9:135-44.

Ciuffetti, L. M., Francl, L. J., Ballance, G. M., Bockus, W. W., Lamari, L., Meinhardt, S. W., and Rassmussen, J. B. 1998. Standardization of toxin nomenclature in the Pyrenophora tritici-repentis/wheat interaction. Can. J. Plant Pathol. 20:421-424.

De Wolf, E. D., Effertz, R. J., Ali, S., and Francl, L. J. 1998. Vistas of tan spot research. Can. J. Plant Pathol. 20:349-444.

Faris, J. D., Anderson, J. A., Francl, L. J., and Jordahl, J. G. 1997. RFLP mapping of resistance to chlorosis induction by Pyrenophora triticirepentis in wheat. Theor. Appl. Genet. 94:98-104.

Gurr, S. J., Unkles, S. E., and Kinghorn, J. R. 1987. The structure and organization of nuclear genes of filamentous fungi. Pages 93-139 in: Gene Structure in Eukaryotic Microbes. J. R. Kinghorn, ed. IRL Press, Oxford, U.K.

Lamari, L., Sayoud, R., Boulif, M., and Bernier, C. C. 1995. Identification of a new race in Pyrenophora tritici-repentis: Implications for the current pathotype classification system. Can. J. Plant Pathol. 17:312-318.

Liu, Y. G., and Whittier, R. F. 1995. Thermal asymmetric interlaced PCR: Automatable amplification and sequencing of insert end fragments from P1 and YAC clones for chromosome walking. Genomics 25:674-681.

Liu, Y. G., Mitsukawa, N., Oosumi, T., and Whittier, R. F. 1995. Efficient isolation and mapping of Arabidopsis thaliana T-DNA insert junctions by thermal asymmetric interlaced PCR. Plant J. 8:457-463.

Martoglio, B., and Dobberstein, B. 1998. Signal sequences: More than just greasy peptides. Trends Cell Biol. 8:410-415.

Orolaza, N. P., Lamari, L., and Ballance, G. M. 1995. Evidence of a host-specific chlorosis toxin from Pyrenophora tritici-repentis, the causal agent of tan spot of wheat. Phytopathology 85:1282-1287.

Strelkov, S. E., Lamari, L., and Ballance, G. M. 1999. Characterization of a host-specific protein toxin (Ptr ToxB) from Pyrenophora triticirepentis. Mol. Plant-Microbe Interact. 12:728-732.

Tomas, A., Feng, G. H., Reech, G. R., Bockus, W. W., and Leach, J. E. 1990. Purification of a cultivar-specific toxin of Pyrenophora triticirepentis, causal agent of tan spot of wheat. Mol. Plant-Microbe Interact. 3:221-224.

Tuori, R. P., Wolpert, T. J., and Ciuffetti, L. M. 1995. Purification and immunological characterization of toxic components from cultures of Pyrenophora tritici-repentis. Mol. Plant-Microbe Interact. 8:41-48.

Zhang, H.-F., Francl, L. J., Jordahl, J. G., and Meinhardt, S. W. 1997. Structural and physical properties of a necrosis-inducing toxin from Pyrenophora tritici-repentis. Phytopathology 87:154-160. 